University of Nebraska - Lincoln

DigitalCommons@University of Nebraska - Lincoln

Sociology Department, Faculty Publications

Sociology, Department of

2-2006

\title{
Models of American Indian Education: Cultural Inclusion and the Family/Community/School Linkage
}

\author{
Adrienne Freng \\ University of Wyoming, afreng@uwyo.edu \\ Scott Freng \\ University of Wyoming, sfreng@uwyo.edu \\ Helen A. Moore \\ University of Nebraska-Lincoln, hmoore1@unl.edu
}

Follow this and additional works at: https://digitalcommons.unl.edu/sociologyfacpub

Part of the Sociology Commons

Freng, Adrienne; Freng, Scott; and Moore, Helen A., "Models of American Indian Education: Cultural Inclusion and the Family/Community/School Linkage" (2006). Sociology Department, Faculty Publications. 89.

https://digitalcommons.unl.edu/sociologyfacpub/89

This Article is brought to you for free and open access by the Sociology, Department of at DigitalCommons@University of Nebraska - Lincoln. It has been accepted for inclusion in Sociology Department, Faculty Publications by an authorized administrator of DigitalCommons@University of Nebraska - Lincoln. 


\title{
MODELS OF AMERICAN INDIAN EDUCATION: CULTURAL INCLUSION AND THE FAMILY/COMMUNITY/ SCHOOL LINKAGE*
}

\author{
ADRIENNE FRENG \\ University of Wyoming \\ SCOTT FRENG \\ University of Wyoming
}

HELEN A. MOORE

University of Nebraska-Lincoln

\begin{abstract}
Educational research has explored the impact of culture and the linkage of families and communities to schools on student achievement among minority students. Little focus, however, has been placed on the family/community interactions with schools among culturally distinctive populations such as American Indians and students' perceptions of the educational process. This exploratory research examined the state of education from the perspective of American Indian young adults from various tribes in Nebraska. Instead of focusing on educational achievement, the emphasis of most educational research relating to American Indians, this study explored the model of education in existence. Additionally, researchers explored the respondents' interpretations of the role of culture and language in the public school system and its link to the family/community/school interaction. Qualitative thematic analyses of the responses highlight themes of an educational system that largely ignores American Indians' unique cultural and educational needs and represents a separate sphere from the community and family (Charleston 1994; Epstein 1995).
\end{abstract}

\footnotetext{
*An earlier version of this paper was presented at the National Association of Native American Studies Conference, Houston TX, February, 2000. The original research was supported by a grant from the University of NebraskaLincoln Research Council: IRB \#98-07-422EP. The points of view in this article are the authors and do not necessarily represent those of the research council. We would like to thank the individuals who contributed their stories in order for us to complete this research and the peer interviewers who listened to those stories. We would also like to thank the reviewers at Sociological Focus for their insightful comments. Correspondence concerning this article should be addressed to Adrienne Freng, University of Wyoming, Department of Criminal Justice, 1000 E. University, Dept. 3197, Laramie, WY 82071. Phone number: 307-766-2307. E-mail: afreng@uwyo.edu.
} 
In this era of multiculturalism and "no child left behind" policies, considerable debate exists on the best strategies for education, especially for culturally distinct populations (Banks and Banks 1996; Gollnick and Chinn 1998). For American Indian students, who continually have lower academic achievement rates than other racial/ethnic groups (No Child Left Behind 2002), the purpose and content of the curriculum is of importance. Also key to this issue is the family/community/school interaction and the impact of this relationship on the educational outcomes of American Indian students. These elements are central to several proposed frameworks that describe how the cultural and linguistic backgrounds of American Indians are tied to the role that family and community play in the educational process. While the assimilationist model focuses on integrating American Indians into dominant eulture (Berry 1980), Charleston (1994) and Epstein's (1995) models emphasize the collaboration among schools, families, and the community in the transmission of culture and language.

American Indian schooling is too often cast by educational researchers and policy makers (especially non-Indians) to reflect the norms and expectations constructed by the dominant group. Because American Indian populations have lower graduation rates and higher dropout rates than any other racial/ethnic group (Kaufman et al. 1999; No Child Left Behind 2002), policy makers are likely to focus on a deficiency explanation for American Indian education (Charleston 1994). This model suggests that "Indian children or their cultures or communities have been solely responsible for" lower achievement (Robinson-Zanartu and Majel-Dixon 1996:34). Therefore, assimilation into mainstream American society through increased education is assumed to be "the obvious solution to the problems facing American Indians" (Charleston 1994:19; Deyhle and Swisher 1997). The assimilationist model ignores the language and cultural differences between schools and communities that ultimately affect the educational outcomes for American Indian students (Charleston 1994; Robinson-Zanartu and Majel-Dixon 1996; Tempest 1998). Educational policies founded on assimilation have followed a framework of deculturalization in which indigenous languages and cultures are stripped away and replaced in the educational process (Spring 1997; Szasz 1999).

In contrast, many American Indian communities argue that "intellectually demanding schools that are culturally, linguistically, and developmentally appropriate to their individual and tribal identities" are needed (Charleston 1994:47). Whitbeck and colleagues (2001) found that association with traditional American Indian culture was positively related to school success for American Indian children in the upper Midwest. Furthermore, researchers and policy makers agree that the coordination of parent and school resources best advances student education, especially for underachieving students (Epstein 1995; Lightfoot 1981). To meet the educational needs of American Indian children, Charleston's (1994) model of "true" Native education and Epstein's (1995) model of overlapping spheres propose bringing Indian communities, families, and culture together in the educational process. The conflicting views regarding the means and ends to succeed academically of the assimilationist model and this more inclusive framework lead to several questions: 1) Is there evidence for the fostering of partnerships between family, community, and the schools as proposed by Epstein (1995)? 2) Does the educational experience of American Indian students include the utilization of culture and language as reflected in Charleston's (1994) "true" Native education model? and 3) Based on the models present, how do students perceive their position in the educational system? 
In providing a preliminary examination of the inclusion of culture/language and the extent to which the family/community/school connection exists, this paper first outlines the history of educational policy towards American Indians, including the role of community in traditional educational practices. Next, to provide a framework for the thematic analysis of interviews, several theoretical models of education are discussed including Charleston's (1994) model of "true" Native education and Epstein's (1995) framework. Using these models, interviews with former students were analyzed to determine the model of education characterized by their educational experiences and the perceptions of their role in the educational arena. Specifically, did participants' perceive an educational experience that most closely resembled a model of "pseudo," "quasi," or "true" Native education (Charleston 1994)? Furthermore, we examined whether the family/community/school linkage for these students represented a model of separate or overlapping spheres (Epstein 1995). Finally, we contemplate how these results impact and further discussions regarding current educational policy.

\section{AMERICAN INDIAN EDUCATION POLICY IN THE UNITED STATES}

To understand the current state of American Indian education, an overview of educational policy involving this population is needed. Historically, American Indian societies have highly valued education (Cajete 1994). Tribal/Indigenous education of American Indian children was a community effort and responsibility (DeJong 1993; Nichols 1930; Szasz 1988, 1999). These educational systems focused on interactive and imitative processes in which different adults participated in teaching children various skills (DeJong 1993; Demmert 2001; Nichols 1930; Szasz 1988). In contrast to American classrooms where competition is stressed, a philosophy of cooperation was emphasized in traditional American Indian education (Aronson 2004; Child 1998; Coleman 1993; DeJong 1993, p. 5; Szasz 1988).

The responsibility of the United States government for the education of American Indian peoples arose mainly out of treaty obligations (Charleston 1994; DeJong 1993). While these treaties require the United States government to provide education to American Indians, the historical consequences of these policies included moving American Indian populations involuntarily (disrupting social, linguistic, and economic patterns) and attempting to replace indigenous cultural norms and institutions. In fact, the educational system represents the primary institution used to strip away indigenous cultural and social systems (Charleston 1994; DeJong 1993). This assimilationist policy remained in effect through the boarding school era of the 1920s (Adams 1995; Child 1998; Coleman 1993; DeJong 1993; Standing Bear 1988; Szasz 1999).

In 1928, the Meriam Report concluded that boarding schools had failed to accomplish assimilation goals (Child 1998; DeJong 1993; Deyhle and Swisher 1997; Szasz 1999). In response, the Meriam Report proposed decreasing the number of offreservation boarding schools and increasing the number of on-reservation schools (Child 1998; Deyhle and Swisher 1997). Later, the Johnson-O'Malley Act (1934) transferred students from federal Bureau of Indian Affairs schools to state funded public schools (DeJong 1993; Szasz 1999).

Beginning in the $1960 \mathrm{~s}$, a movement towards self-determination and increasing local Indian control over education developed (Deyhle and Swisher 1997; Senese 1991). The Indian Education Act (1972) directed funding to public schools to address the 
cultural and language needs of American Indian students. This Act preceded the Indian Self-Determination and Educational Assistance Act, which allowed tribal control over some federal Indian schools. These two acts remain significant as they initiated programs granting more tribal and community control over educational programs for American Indian students. While these policies permitted some local control over the content of education, these programs still mirrored the structure of traditional White education (Senese 1991).

More recently, a variety of educational policies regarding American Indian education have proliferated. During the 1980 s and 1990 s, the amount of tribal involvement in education varied, but the goal remained the same: to retain control over the education of American Indian children. A renewed interest in increasing language and cultural programs available for American Indian students, not just in reservation schools, but also in primarily White schools appeared. This new focus created the backdrop against which the agenda for recent educational frameworks and policies developed.

\section{THEORETICAL PERSPECTIVE}

Much of the research focusing on American Indian education has tied the educational outcomes of American Indian students to key factors including language, culture, and family/community interactions with the school system (Demmert 2001; Deyhle 1995; Deyhle and Margonis 1995; Deyhle and Swisher 1997; Evans, Okifugi, and Thomas 1995; Lightfoot 1981; Whitbeck et al. 2001). However, while some educators believe American Indian students are not successful because of their cultural and language differences, following a deficiency explanation, other research finds that it is exactly this indigenous culture, language, and family/community interaction that makes students more successful (Demmert 2001; Deyhle 1995; Deyhle and Margonis 1995; Deyhle and Swisher 1997; Dick, Estell, and McCarty 1994; Whitbeck et al. 2001). Based on this latter research, several models of education, integrating the elements of culture, language, and family/community interaction with schools, have been proposed. Specifically, Charleston's (1994) model of “true” Native education and Epstein's (1995) model of overlapping spheres are discussed.

\section{True Native Education}

Charleston's (1994) educational framework discusses the role family, community, and school play in the transmission of culture and language. The colonization experiences theorized by Blauner (1972) and Spring (1997) and the contrasting possibilities for "cultural survival" emphasized by Nagel (1996:72) in her framework of American Indian ethnic and cultural renewal are the basis of these models. Blauner's (1972) explicit conflict model of internal colonization states that minorities who have voluntarily immigrated to the United States with a desire for educational advancement are often in a more congruent position with assimilationist school goals and a functionalist interpretation of schooling. In contrast, historically, American Indians were forced to enter the U.S. educational system (Ogbu 1995). This process resembles "pressure cooker" assimilation, resulting in a "unicultural" society represented by monocultural, monolingual schooling systems that block opportunities for American Indians (Berry 1980:15). Thus, American Indian groups are potentially more resistant to the values of the mainstream, 
including the goals of the educational system, as they struggle for group survival by "endur[ing], adapt[ing], and continu[ing] to develop" as a culture (Ogbu 1995; Nagel 1996:72; Spring 1997; Szasz 1999). Across the framework outlined by Charleston (1994) and others, language and culture serve as key factors in discussions of education, community, and family involvement (See Figure 1).

The first model described by Charleston (1994) is "pseudo" Native education. This schooling process teaches American Indian students a standardized curriculum of English language and European American interpretations of history and culture. The

\section{Figure 1. Charleston's (1994) Theoretical Framework.}
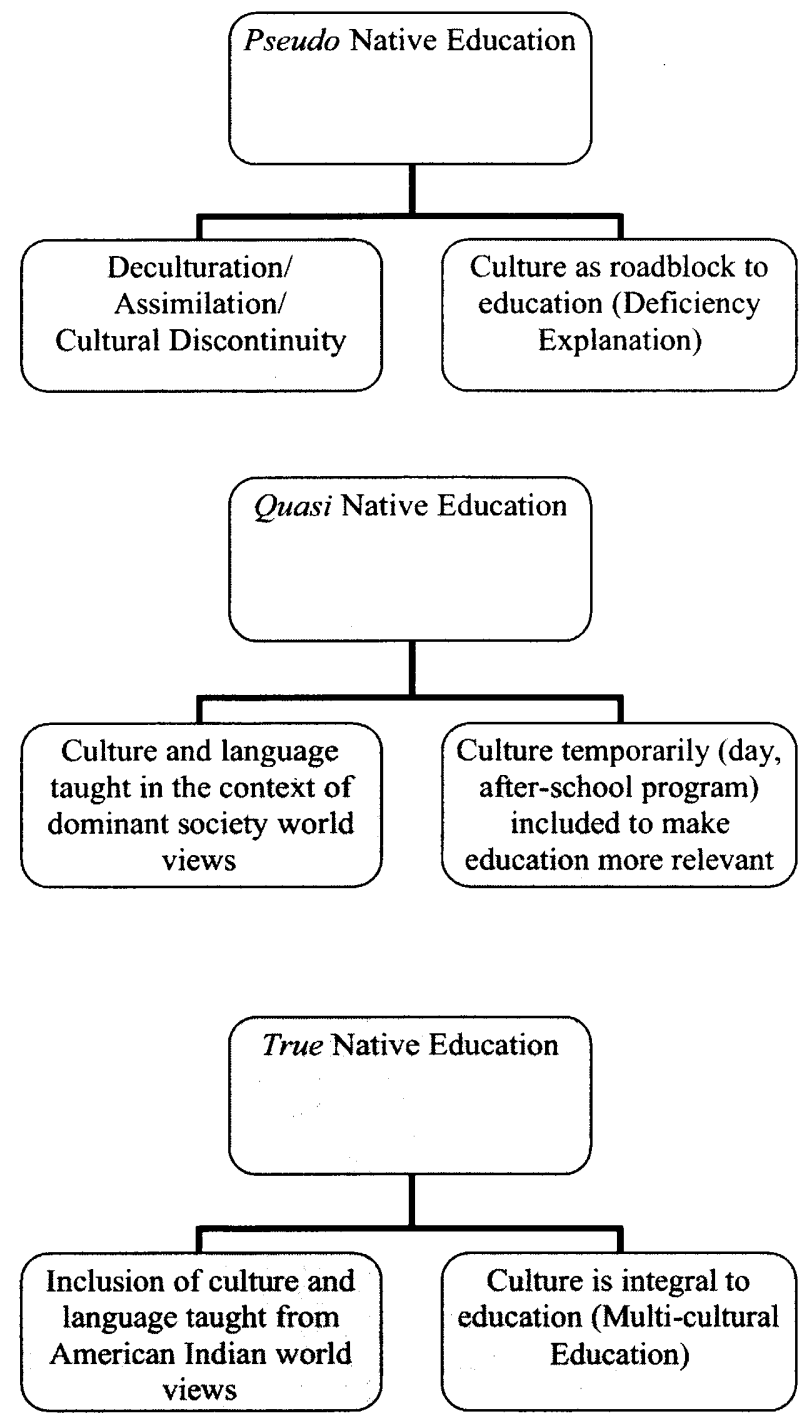
educational goal is to assimilate students into dominant norms. This system of education reflects the functional educational model and rapidly deculturalizes communities and individuals (Banks and Banks 1996; Spring 1997). "Pseudo" education focuses on a deficiency explanation of American Indian education.

The second model is "quasi" Native education, a reformist approach. Charleston (1994: 27) identified it as a system "that sincerely attempts to make American education more culturally relevant and supportive of Native students and Native communities." Charleston (1994:27) described these programs as "add-on, pull-out, or after-school projects operated at the local school" that are generally short term and underfunded. "Quasi" Native education programs rarely have American Indian people in positions of leadership. The goal is to "teach about Native cultural topics with a heavy emphasis on the material culture of beadwork and featherwork" and the history of American Indian peoples as an artifact of contact with White people (Charleston 1994:27). Charleston (1994) noted that this model is better than having no culturally relevant education, but it represents a hidden deculturalization process and accomplishes assimilationist goals nonetheless (Spring 1997).

The core concept of Charleston's (1994) framework is "true" Native education. This model reflects more traditional ways of education among American Indians. Thus, "true" Native education (Charleston 1994:31) relies on local schools to bring together community institutions, parents and elders, the endorsement of the Tribe or Band, and the commitment of all people to learning and teaching. Other guiding principles include providing basic and higher order skills through enriched curricula that draw upon American Indian world views and inspiring personal and community commitment (Cajete 1994; Charleston 1994:32). “True"Native education is also tied to Deloria's (1982) emphasis on the indigenous value of experiential and sacred knowledge to the American Indian community. Deloria asserts that Whites want to teach abstractions, which may not have immediate usefulness to Indian students. These non-tribal educational efforts are constructed around "a preconceived notion of what constitutes useful information and knowledge" (Deloria 1982:59).

\section{The Family/Community Nexus and the Schools}

Recently, educational theory began incorporating collaborative models involving families, communities, and schools in the educational process. Researchers (Connors and Epstein 1995; Epstein 1995; Evans et al. 1995; Lightfoot 1981) report that children's learning excels when families and schools partner to promote education. Recent evidence suggests that parental involvement is an important element in student academic achievement and overshadows other family and individual characteristics (Epstein 1992; Epstein 1995; Griffith 1996; Ward 1995).

To understand differences among educational systems, Epstein (1995) introduced the concept of separate versus overlapping spheres of influence. Separate spheres occur when education is unconnected to the family's influence on the child. In a separate sphere, teachers may expect parents to "observe rather than participate" in education (Lightfoot 1981:98). An example of separate spheres of influence might include a teacher saying "if the family would just do its job, we could do our job" or parents saying "I raised this child, now it's your turn to educate them" (Epstein 1995:702). Traditionally, schools 
operating under separate spheres contact parents only when a problem arises (Epstein 1992; Evans et al. 1995; Lightfoot 1981). Dolce (1985) found that children who view minimal communication between their parents and the school may get the impression that their parents do not care what happens to them in school, or that school is not very important.

Despite the long tradition of separate spheres, educators and parents alike are beginning to recognize the limitations of keeping education apart from the home. Epstein (1995) argued that overlapping spheres of influence are essential to successful education (See Figure 2). An example of overlapping spheres is a parent who says "I make sure my daughter knows that homework comes first" (Epstein 1995:702). Epstein (1995) and Shann (1998) reported that most teachers want parents to be more involved in the educational process, but are unsure how to accomplish this task. Parents, on the other hand, want to help their children succeed at school, but feel they may lack sufficient knowledge or expert status to do so (Epstein 1992; Gettinger and Guetschow 1998; Robinson-Zanartu and Majel-Dixon 1996). Epstein (1992:1143) found that when teachers work with parents to educate children at home as well as at school, teachers raise their expectations of the parents and "appreciate parents as partners." By using overlapping spheres of influence "the shared interests and investments of schools, families and communities create the conditions of caring that work to 'overdetermine' the likelihood of student success" (Epstein 1995:703).

\section{Figure 2}

\section{Epstein's (1995) Model of Overlapping Spheres.}

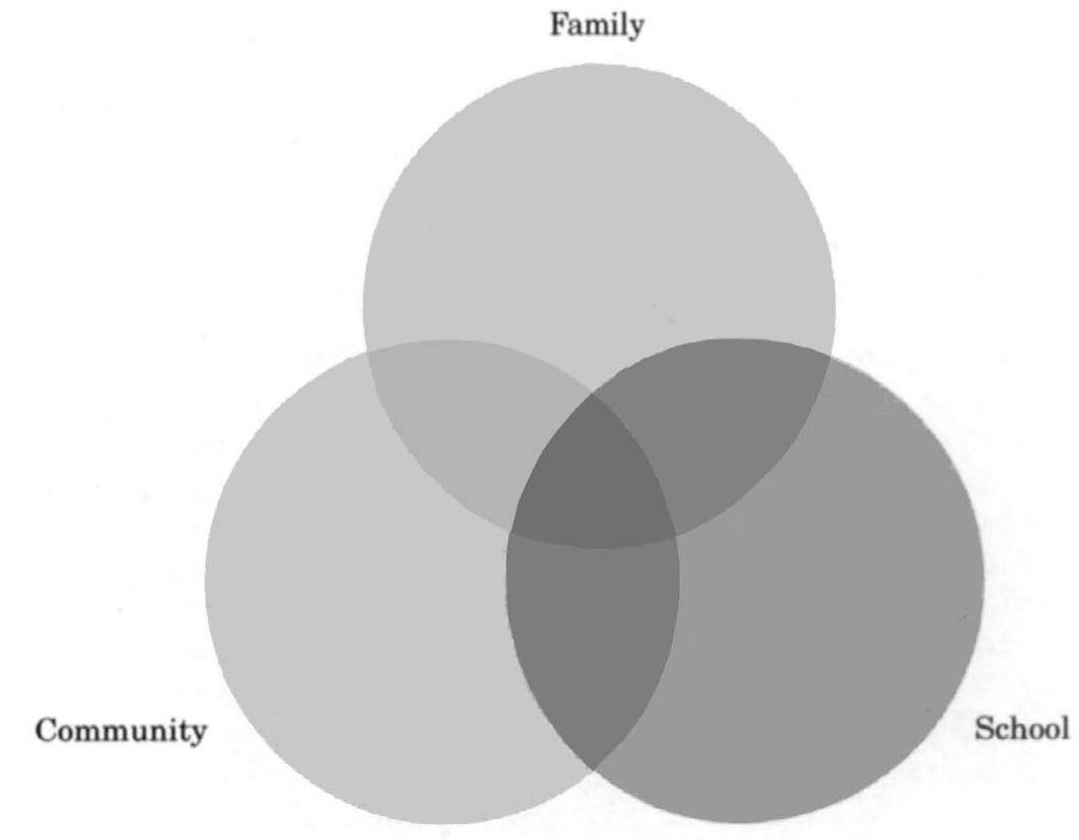


Epstein $(1995 ; 2001)$ offered six types of involvement for creating collaborative, overlapping spheres. These types included: basic obligations of families (providing positive home conditions), basic obligations of schools (school communicates with parents), involvement at school (community members and family members assist in teaching), involvement in learning activities at home (involve children in learning activities at home), involvement in decision making (community and family members serve as advocates and participate in decision-making roles), and collaboration and exchanges with community organizations (community organizations impact children's learning). Involving the community in the collaboration process is evident in school "programs that tap parents' and community members' talents" to enrich student learning experiences (Connors and Epstein 1995:448).

One area in which community and family members' assistance may be especially useful is in the transmission and understanding of culture. In fact, "parents and community members [have] ranked themselves and their culture as very important in the education" of American Indian children (Robinson-Zanartu and Majel-Dixon 1996:38). Unfortunately, elements of culture are often ignored by schools, representing a cultural discontinuity model (Ledlow 1992; Spring 1997; Szasz 1999). Cultural discontinuity is characterized by the use of passive teaching methods, inappropriate testing, tracked classes, distorted curricula, uncaring/untrained teachers, large schools, and a lack of parental involvement in the educational process (Ledlow 1992; Reyhner 1992:37).

\section{Importance of Research}

Currently, research on American Indian education focuses on the impact of elements such as language, culture, and family/community/school interactions on educational achievement. Therefore, several models of American Indian education have been proposed examining the relationship between these factors. However, few researchers have examined whether the family/community/school connection actually exists in the educational arena. Specifically, in this era of self-determination and multiculturalism, do the more inclusive models as proposed by Charleston (1994) and Epstein (1995) actually characterize the educational experiences of American Indian students? The purpose of this research was to examine American Indian students' experiences in U.S. education in the context of the two educational models proposed by Charleston (1994) and Epstein (1995), thus expanding the current literature in several ways.

First, exploring the existence of the educational models proposed by Charleston (1994) and Epstein (1995) will reveal the factors related to student success that appear in the educational system. Since the family/community/school connection and the inclusion of culture and language in the classroom has been tied to educational success, it is important to evaluate whether the curriculum is inclusive or exclusive in terms of these factors (Dick et al. 1994; Robinson-Zanartu and Majel-Dixon 1996; Whitbeck et al. 2001). A system ignoring the family/community/school interaction, as represented by Epstein's (1995) separate spheres effectively devalues parents as partners in the educational process, thereby erecting barriers between the family and school. Thus, input from parents and the community regarding culture and language are effectively ignored, allowing for the perpetuation of what Charleston (1994) would classify as "pseudo" Native education. Therefore, considering the educational models in 
place allows us to evaluate whether key elements related to student achievement are considered by the educational system or need to be incorporated into future educational policy to ensure academic success for these students.

Additionally, this research explores the impact of the inclusion or exclusion of these factors on American Indian students' perceptions of their place in the educational system. Although largely ignored, students' perceptions of these interactions and the model of education they perceive being implemented is an essential component of educational policy (Epstein 2001). Furthermore, research has shown that culture/ language and the family/community/school connection is essential to the educational process (Demmert 2001; Deyhle 1995; Deyhle and Margonis 1995; Deyhle and Swisher 1997; Dick, Estell, and McCarty 1994; Epstein 1995; Lightfoot 1981; Whitbeck et al. 2001). Thus, evaluating students' perceptions can provide important insight into the specific mechanisms by which this relationship impacts the involvement of American Indians in the educational arena. Research suggests that students' perceptions regarding the lack of family/school interaction can lead to the assumption by students that education is not important, thus affecting their educational attainment (Dolce 1985). Moreover, previous research indicates that both student and teacher perceptions influence the academic performance of students (i.e. stereotype threat and self-fulfilling prophecy) (e.g., Rosenthal and Jacobson 1966; Steele 1997; Steele and Aronson 1995). To address these issues, this research focuses on the assessment and influence of the educational model present through the exploration of former students' perceptions about cultural and language inclusion, as well as family/community involvement in their schooling.

\section{METHODOLOGY}

\section{Interviewer Selection and Training}

Recent perspectives on conducting research with minority populations have called for culturally respectful and competent practices (Becerra and Zambrana 1985; Day, Blue, and Raymond 1998; Miller Cleary and Peacock 1998). To address this issue, we used a peer interviewer model, amending the interviewing methods developed by Miller Cleary and Peacock (1998) in their research with Indian and non-Indian teachers. As non-Indian researchers at a large state university, we were concerned about respondent willingness to address questions and possible interviewer effects, as well as crosscultural miscommunication. After consulting with a number of American Indian colleagues and students, we established a protocol to bring American Indian peer interviewers into partnership with the research team. This process allowed participants to share their stories one-on-one with other American Indians instead of non-Indian researchers, facilitating a more open atmosphere in which to complete the interview. In our project, four American Indian social science college students in Nebraska were recruited to participate in interviewer activities through the Nebraska Indian Education Association and the University Native American Studies Program. As part of their training, peer interviewers learned interview techniques, discussed issues that might arise in the interview process, and practiced these techniques with other peer interviewers. The four peer interviewers used a snowball sampling process to identify and conduct semi-structured interviews with non-family members. This procedure resulted in 16 interviews, representing an adequate sample size for a phenomenological study (Creswell 1998). Incentives for participation in this research included a stipend to 
both the peer interviewers and the respondents as recognition of the time contributed to the study.

\section{Interview Process}

At the interview, respondents read and signed an informed consent form. All interviews were taped, transcribed to anonymous code sheets, and the original tapes were destroyed. The semi-structured interview questions focused on three areas: student perceptions of their family and community interactions with the schools; the quality and inclusion of the American Indian cultural content of the curriculum; and student experiences and role expectations in elementary school and high school.

\section{Sample}

Sixteen American Indian individuals (10 males and six females) were interviewed. Respondents attended Nebraska public schools at some point in their educations, and were between the ages of 18 and 25 at the time of the study. The final pool of participants included American Indians from five different tribes. The primary affiliation was with the Ho-Chunk or Winnebago tribe (7), with other tribal affiliations including Omaha (3), Santee (3), Lakota (2), and Cheyenne (1). Educational outcomes ranged from college or community college attendance (12) to those who left school without a high school diploma (4). Half of the respondents attended public schools on a reservation exclusively (8), while the remaining participants attended either non-reservation schools (4) or a combination of reservation and non-reservation schools (4).

\section{Analytic Strategy}

The interview content was organized into themes/patterns using analytic induction methods (Bogdan and Biklen 1997; Glaser and Strauss 1967). This approach involves "identify[ing] the dimensions or themes, which seem meaningful" (Abrahamson 1983:286). During the analysis process, we identified themes in the interviews and revised them as materials contradicting or expanding the initial themes were gathered. To ensure the reliability of themes, each interview was independently coded by three persons. Any disagreements in coding were resolved through discussion. Using the analytic induction method, researchers identified seven themes: 1) parent/family interaction with schools; 2) access to Indian culture in the schools; 3) interaction with indigenous culture/language; 4 ) interaction with White students and dominant culture; 5) perceptions of schools, resources, and teachers; 6) view of self as student; and 7) role models. While the first three themes directly address the primary research questions, information from several of the other themes (e.g. interaction with White students and dominant culture; perceptions of schools, resources, and teachers; view of self as student) are discussed in the analysis when they related to the primary research questions.

\section{THEMATIC ANALYSIS}

Culture, language, and the interaction between families, communities, and schools are central factors in the various models of American Indian education. Charleston's (1994) framework focuses on culture and language inclusion, while the family/community nexus is emphasized by Epstein's (1995) model. In addition to examining these factors in the context of the educational model present, it is important to understand whether 
the inclusion or exclusion of these factors influenced participants' perceptions of the educational system and their position in it. These relationships were explored within the context of American Indian participants' responses to questions toward culture and language inclusion and family/school collaboration discussed in the following sections.

\section{Cultural Dimensions within Education}

In an assimilationist model of education, facts regarding the dominant group are emphasized (Banks and Banks 1996). Thus, for minority students, the information regarding their culture may be non-existent or disseminated in a negative fashion. The general consensus among our participants, including those who attended reservation schools, was that the cultural background of American Indian students was largely ignored in their school experiences. This was particularly troubling within reservation schools where American Indian culture presumably could and should be included. This failure to address differing cultural backgrounds in the school system led many students to question not only their identities, but also their place within the educational process.

Many respondents reported that their culture was not discussed within the school and thus the curriculum was irrelevant to them.

I don't remember the school teaching me anything about my culture. I know once in awhile they had like speakers come in who were American Indian, but they never talked about culture, they talked about other things like drugs and they had a presentation about um ... Veterans Day. But, none of it was about culture, it was all about these White aspects of life that American Indians were involved in.

Another stated that American Indian culture was not addressed, "I don't think there was any classes or anything. It wasn't encouraged or ... [there] wasn't the opportunity to explore, wasn't even given, I don't think in any of my classes that I did take." In addition, sometimes the information the students received was not only irrelevant, but also negative:

The American history book that we read ... they were all written by non-Indians. They had nothing to do with Native Americans in it. And the small pieces they did have in there were negative.

This lack of information regarding American Indian culture and the negative portrayal of American Indian culture resulted in some participants questioning the actions of teachers in their schools. One commented on a supposed cultural activity:

I remember we were in second grade, our teachers made us make feather like war bonnets out of construction paper for Thanksgiving. And I distinctly remember this, cause now as I'm older, I'm like that was really racist of her to do that.

Identity issues also appeared for respondents. These were manifested in a variety of ways, but were tied to a lack of American Indian culture within the school system. Individuals had difficulty identifying with teachers because "none of them were American Indian, they were all White." While identity issues were present for all participants, many from reservation schools commented on how their identity was influenced by interactions with students from majority White schools. 
I always wanted to be, I mean you know, be on my best behavior and wanted to impress people because we were an all Indian school. I wanted to give them that impression you know that um, that American Indians are good, I mean they are just as good as anyone else.... I think there are a lot of schools still that look down on Winnebago because we are an American Indian school.

Another perceived their identity with an all Indian school as a way to increase their cultural identity as Indian.

At Winnebago, I was proud to be 'Winnebago Indians.' That was like our team we played in sports. We were the 'Winnebago Indians' and we really were Indians. Like almost our whole team was Indian. And I was proud of that because I am Winnebago.

These interactions with the majority culture led some respondents to question their positions, not only in the dominant culture, but in the Indian culture as well.

My mom came to one of my classes and she made fry bread for everybody and stuff and
it was like a week that we learned about Indians and whatnot and that always put me in
kind of an awkward position because it was expected of me to be living in a teepee and
wearing moccasins and speaking Indian and whatnot. I was just like 'what are you guys
talking about, you know I know as much as you.' So that always kind of made me feel like
you know it made me look at myself and say 'why don't I know as much about...'

The responses of these individuals regarding the cultural dimensions of education reflected an educational experience somewhere between Charleston's (1994) "pseudo" and "quasi" Native educational models (See Table 1). While many individuals indicated that American Indian culture was ignored or discussed in a negative manner, some pointed to minor programs addressing culture. However, the consensus among the participants was that American Indian culture was largely non-existent in their educational studies. From the participants' perspective, the omission of culture by the schools led to the inclusion of inappropriate curricula and indicated a lack of community collaboration in the transmission of culture (Conners and Epstein 1995; Reyhner 1992). If the presence of American Indian language and culture is a key element to educational success among American Indian students as proposed by Charleston (1994) and others (Crawford 1992; DeJong 1998; Mehan 1992; Spring 1997; Szasz 1999; Whitbeck et al. 2001), then these responses indicate a pressing need for cultural inclusion.

Describing an educational system that ignored their cultural background led many participants to question their individual identity. Charleston (1994) states that education characterized by the dominant culture and assimilation creates contradictions for American Indian students. Students are caught between the assimilationist goals of the public schools and the struggles for cultural continuity in their communities. Tierney (1993:320) framed this dilemma as American Indian students being forced to choose between maintaining their culture and "risk economic and social problems, or eschew [their] culture" and gain an education. In realizing an education, many students described themselves as "acting White" in order to successfully navigate the educational system. Since the rewards of larger society (occupational achievements, income, quality of life) flow to those who succeed in the educational system, American Indian students must react by participating in an educational system that largely ignores their cultural background (Collins 1971). 


\section{Table 1. Interview Themes for} Charleston's (1994) and Epstein's (1995) Models

Themes of Cultural and Language Inclusion (Charleston's Model)a

\begin{tabular}{|c|c|c|}
\hline Inclusion & \multicolumn{2}{|c|}{ Cultural Inclusion } \\
\hline Pseudo $^{b}$ & & \\
\hline Elementary & \multicolumn{2}{|c|}{7} \\
\hline Junior High/High School & \multicolumn{2}{|c|}{5} \\
\hline Quasi $^{\mathrm{c}}$ & \multirow{2}{*}{\multicolumn{2}{|c|}{3}} \\
\hline Elementary & & \\
\hline Junior High/High School & \multicolumn{2}{|c|}{6} \\
\hline True $^{d}$ & \multirow{2}{*}{\multicolumn{2}{|c|}{2}} \\
\hline Elementary & & \\
\hline Junior High/High School & \multicolumn{2}{|c|}{1} \\
\hline \multicolumn{2}{|l|}{ Epstein's Six Types of Involvement } & Present \\
\hline $\begin{array}{l}\text { Basic obligations of families } \\
\text { Elementary }\end{array}$ & & 5 \\
\hline Junior High/High School & & 3 \\
\hline \multicolumn{3}{|l|}{ Basic obligations of schools } \\
\hline Junior High/High School & & 8 \\
\hline \multicolumn{3}{|l|}{ Involvement at school ${ }^{f}$} \\
\hline Junior High/High School & & 8 \\
\hline \multicolumn{3}{|c|}{ Involvement in learning activities at home } \\
\hline Junior High/High School & & 1 \\
\hline \multicolumn{3}{|l|}{ Involvement in decision making } \\
\hline Junior High/High School & & 2 \\
\hline \multicolumn{3}{|l|}{$\begin{array}{l}\text { Collaboration and exchanges } \\
\text { with community organizations }\end{array}$} \\
\hline Junior High/High School & & 2 \\
\hline
\end{tabular}

aParticipants were scored separately for elementary and junior/high school. So a person who reports no cultural inclusion for elementary school, but reports a day where culture was discussed in junior/high school, scores once for Pseudo and once for Quasi. In addition, not all participants commented on each theme. Finally, it should be mentioned that when computing this tally, the authors attempted to be very liberal. For instance, any mention of culture being included was counted as supporting Quasi instead of Pseudo even though this may have been the only mention of cultural inclusion. In addition, any mention of an entire class built into the curriculum to address American Indian history or culture was counted as True, rather than Quasi.

'Reported "No" cultural inclusion.

"Reported some cultural inclusion either on a special day, week, or other period of time. Not integrated into typical curriculum.

${ }^{d}$ Cultural inclusion built into the curriculum. However, even these examples were typically limited to a single class or only implemented for a few years (e.g. "up until 4th grade... they didn't after that").

'Most of the participants' statements fitting this description were simply an indication that their parents attended parent-teacher conferences.

'Many of these statements reflected parents coming to school related events (athletics, band recitals, etc.). 


\section{Language and Voice}

As with American Indian culture in general, American Indian languages were also largely omitted in the schools and were "not even on the reservations," as one respondent noted. Most participants reported that no opportunities to learn indigenous language in schools existed. As one respondent stated: "the only language I learned was Spanish and I didn't want to learn it and so I wanted to learn my own language and I always complained to my parents." Another individual made reference to the fact that other languages were being taught such as Spanish, but not American Indian language: "I thought it was not right, us being an American Indian community and not having an American Indian language class. I mean, you know, I wish we had the Winnebago language, culture."

If participants did learn indigenous language in their schools, it was often through a token event and not as a permanent part of the curriculum. One individual reported that elders would be invited sporadically to come in and teach in native language "about how to address people" and "how to do, like, the alphabet; learn about colors." Another stated that, "Just once, I think it was second grade we had a teacher that was from here and she would try to say a few Indian words and stuff. But that was probably the only teacher because she was Indian." One individual learned elements of his/her tribal language by:

looking at books and stuff. They had words or phrases. Some of them had stories that were translated into English on one page and then on the other page it had them in Hochunk [Winnebago]. And I tried to make it out best that you can with what you know.

These comments about language reflected education represented by both the "pseudo" and "quasi" educational models described by Charleston (1994--see Table 1). Native language was non-existent or placed in a fragmented, secondary role in the educational system. The comment that Spanish was an acceptable language to learn, while Winnebago language was not, clearly illustrates the extent to which the students felt the Native language was devalued in the curriculum. These responses suggest a separate spheres model, while Epstein (1995) proposes overlapping spheres representing collaboration between community and schools (See Table 1). Participants described the importance of community members as central to the transmission of language and culture, but this collaboration between the community and school was often absent.

\section{Family/Community/School Interaction}

From the standpoint of these participants, their lack of access to the language and culture of their communities was an important factor in their educational experiences. The absence of family/community/school interaction also emerged as an important theme. Charleston's (1994) model of "true" Native education, in addition to Epstein's (1995) overlapping spheres incorporates schools, families, and communities into the educational process. However, assimilationist goals of education can prevent connections between home/community and school.

This lack of interaction can be seen in the responses regarding parents' involvement in the school setting. The overwhelming majority of respondents reported that the relationship between their parents and teachers was either non-existent or very superficial as indicated by statements such as "there was rarely any interaction between my parents and my teachers." One individual was very aware of the level of 
interaction between their parents and the schools and stated that "she would say 'hi' to them and 'how are you' and just like first level of interaction type of stuff. She really didn't know them really well." Many of the participants reported that their parents had interaction with the schools only when they "had to" come or when a teacher had concerns. As another stated, their parents were always at the school "because I was always in trouble." Many individuals reported that the primary interaction between their parents and the school system was through traditional parent-teacher conferences, "My mom always went to our parent teacher conferences. I think that is the only time she ever went to the school."

While most respondents reported little interaction between the school system and their parents, some reported positive experiences of parent/school interaction under some conditions. These interactions were often associated with having parents who held a formal position within the school system. One individual reported that her mom:

is currently on the school board right now so she's um has plays a big part in all their lives. All the teachers, administration. Everyone. She knows about all of them actually. She knows who's always on top of their job and the ones that aren't.

A second individual stated that:

My mom was really involved ... If there was problem, she would go up there right away and find out not in a bad way, but she would go investigate what's going on. She always went to the parent teacher conferences ... And she was on the school board for a long time.

In addition to parental involvement in the school system, encouraging experiences were linked to teachers who interacted positively with the respondents and parents:

I told my mom and she told the teacher and then like after school we'd stay after and my mom would be there and he would be there and we would try to figure out ways for me to learn the science part of the class.

Interactions between parents and teachers characterized another individual's comments, "my parents, they got along with the teachers good. They knew them on a first name basis ... There was a lot of positive energy between my parents and my teachers."

While a small number of responses portrayed elements of overlapping spheres, these family/school/community interactions represented only a narrow range of activities proposed by Epstein (1995), such as basic obligations of schools (See Table 1). For the majority of respondents, however, interactions were characterized by separate spheres in which the community and family influences were ignored by school representatives (Epstein 1995). For these participants, state supported schools rarely linked their families and communities in a meaningful way. These fragmented contacts, omissions and distortions of culture, and a lack of language once again reflected a departure from Charleston's (1994) true Native education and failed to reflect the six types of involvement proposed by Epstein (1995). Unfortunately, the lack of overlapping spheres may lead students to believe that their parents do not care about their education, or that school is not important (Dolce 1985). 


\section{DISCUSSION AND CONCLUSION}

\section{Research Overview}

This exploratory research sought to expand the current literature by examining whether, in this era of self-determination and multiculturalism, an assimilationist model or a more inclusive model of education represented American Indian educational experiences. Furthermore, the analysis explored how the inclusion/exclusion of culture/language and the family/community/school nexus influenced the participants' perceptions of their place in the educational arena. These results suggest that the educational system experienced by young adults today still holds a strongly assimiliationist approach to American Indian education. The schooling process is determined by non-Indian policy makers and reflects a deculturalization approach to language and community (Spring 1997; Szasz 1999). While educational policies have tried to encourage more culturally relevant curriculum in the classroom, our participants' responses indicated that this is not occurring. The themes of cultural and linguistic maintenance for tribal identity as described by our respondents did not reflect Charleston's (1994) "true" Native education. Instead, these former students described their public education as marked by the "pseudo" along with elements of "quasi" Indian education goals (Charleston 1994; see Table 1).

The omission or distortion of tribal language and culture, combined with the invisibility of Indian people in public school teaching and administration, illustrates Epstein's (1995) analysis of separate spheres. Furthermore, little evidence for any of the six types of collaborative involvement emerged in the responses (See Table 1). Communities and families from Indian country were not routinely included in the educational process. Communication between the school and the family/community was unidirectional, often based on a teacher's calls to parents when they were needed in disciplinary or deficiency issues. American Indian parents who did participate in the school-oriented parent/teacher conferences lacked the cultural and language support structures that European American parents take for granted. The rituals of parent/ teacher conferences that are based on monolingual, monocultural assimilation models are inadequate to bridge these separate spheres. Since this connection has been tied to academic success (Demmert 2001; Deyhle 1995; Deyhle and Margonis 1995; Deyhle and Swisher 1997; Dick, Estell, and McCarty 1994; Epstein 1995; Lightfoot 1981; Whitbeck et al. 2001), these results indicate a need to reevaluate practices of including families in the educational process to ensure educational achievement among these students.

\section{Research Implications}

This research, while exploratory in nature, found consistent themes (See Table 1) that outline implications for sociological research and areas for further exploration. In addition, this inquiry sought to advance knowledge in not only American Indian issues, but in the educational literature as well. Specifically, this study examined a student perspective from an overlooked population, attempted to apply existing educational models, and assessed the relationship between educational policy and practice.

Focused on the students' perspectives, this research offers unique insights into educational experiences specific to students. While only one piece of a very complex puzzle, it is one that has been largely ignored to this point. While research has linked cultural inclusion and the family/school interaction with academic achievement (Dick 
et al. 1994; Robinson-Zanartu and Majel-Dixon 1996; Whitbeck et al. 2001), the student perspective can provide valuable insight into the mechanisms by which these factors may lead to improved academic performance. Additionally, examining students' perceptions is an essential component in the evaluation of whether students, families, and school officials perceive similar models in place within the educational system. For example, if students perceive an assimilationist model, while school administrators believe they are implementing a "true" Native educational model, steps need to be taken to bring these views into congruence. Thus, while this research emphasized the viewpoints of students, the perceptions of other partners in the educational system are integral to the understanding of educational issues among American Indians. Exploring whether students' perceptions match those of other educational stakeholders, such as families, school officials, teachers, and community leaders, is an area for further exploration.

American Indians represent another population often overlooked in sociological and educational research and thus this study furthers understanding of the educational experiences of this particular group. We found that participants' experiences were strikingly similar despite their different tribal and cultural backgrounds, the level of educational attainment, and the type of schools attended. Although this research was exploratory in nature and thus precludes generalizations of these results to the larger American Indian population, the shared experiences of respondents indicate that perceptions of education might look remarkably comparable. However, this preliminary research sets the groundwork for an examination of these issues with a larger and more heterogeneous sample of American Indians (e.g., tribal affiliation, educational attainment, types of schools). Examining these issues with a larger sample is necessary to assess the universality of these experiences. For instance, is there evidence of a general "American Indian" experience, or are there unique pockets of specific experiences?

This research examined Charleston's (1994) framework for American Indian education and applied Epstein's (1995) model of education to American Indians. While Charleston (1994) proposed "true" Native education as the ideal model for American Indian education, little research has examined the existence of this model in the educational arena. Furthermore, a paucity of research has explored the prevalence of overlapping spheres in the education of American Indians (Epstein 1995). The relative failure to uncover descriptions of "true" Native education and overlapping spheres in the educational experiences of these former American Indian students indicates a need for continuing dialogue among tribes, parents, and schools.

The educational experiences of these American Indian participants indicate a pressing need for the inclusion of American Indians in discussions of educational philosophy and implementation. Participants' responses provided a glimpse into the fit, or lack thereof, between educational policy and practice. Since the early 1970s, educational policies have pushed for more cultural and language inclusion in the education of American Indian students (e.g., Indian Education Act, Indian Self-Determination and Educational Assistance Act). However, it is obvious from the responses of American Indian participants that policy and practice did not coincide. Further assessment of multicultural education programs as implemented is needed to ascertain their reflection of "true" Native education.

Finally, this preliminary research may suggest ways of quantifying the educational experiences of American Indians as they relate to both Charleston's (1994) and Epstein's (1995) models. Specifically, the themes identified in this study combined with detail 
taken from Charleston's (1994) model and items previously used by Epstein (2001), could lead to the development of a scale or scales that might be used to gather data with larger, more heterogeneous samples of American Indians. The existence of specific models of education could then be related to objective measures of academic performance and educational attainment.

\section{Policy and Practice Implications}

In this era of multiculturalism and "no child left behind" policies, the results of this study can provide important insight into the educational experiences of American Indian students. The voices of our participants highlight key areas of policy contradictions that complicate discussions of Indian educational issues. Although "no child left behind" is a recent development in educational policy, historically, American Indians students have always been "left behind" resulting in the lowest academic achievement rates of all racial/ ethnic groups (No Child Left Behind 2002). Additionally, "no child left behind" policies diminish local control contradicting the tenets that Epstein (1995) and Charleston (1994) espouse. If this new policy continues the deficiency model by emphasizing educational achievement through traditional means instead of incorporating multicultural programs with elements of "true" Native education and overlapping spheres in the educational system, the detrimental effects for American Indian students will continue.

From the standpoint of our participants, schools provided few opportunities for cultural survival. This may account for lower educational achievement, as supported by the findings of Whitbeck and colleagues (2001). They found that students exposed to minimal Native culture performed worse academically than students who were more enculturated in traditional Native culture (Whitbeck et al. 2001). Additionally, language maintenance programs, important to Tribal/Indigenous education (Cajete 1994; Szasz 1999; Whitbeck et al. 2001), conflict with current "English Only" programs that reflect continued assimilationist goals (Nagel 1996; Szasz 1999).

To prevent another generation of American Indians from "being left behind," the family/school/community linkage must be integrated with the visions of "true" Indian education as posed by Cajete (1994) and Charleston (1994). Examples of these schooland community-based efforts do flourish in some states (Deyhle and Swisher 1997). The environmental science and tribal government studies programs at the Santa Fe Indian High School is one such Community Based Education Model (CBEM) (Chavez and Pecos 2000). They have established a partnership with the tribal communities that have resulted in the delivery of culturally imbedded curricula, empowering the communities with increased student knowledge, interest, and motivation. While this program is conducted within a tribally controlled school rather than a public school system, many of its practices could be adopted in the public school system, especially those school districts on reservations. The inclusion of these programs, in addition to increasing positive experiences among students by addressing such concerns as teachers' acceptance and willingness to support students, could assist an educational system in achieving a model closer to Charleston's (1994) "true" Native education and Epstein's (1995) overlapping spheres. Without the continuation and expansion of this synchrony of visions, the spirit and legacy of Indian education will continue to be mired into the next generation and opportunities for bridges among schools, Native communities, and American Indian families will be lost. 
Adrienne Freng is Assistant Professor in the Department of Criminal Justice at the University of Wyoming. Her research interests include juvenile delinquency, gangs, and race issues (specifically those dealing with American Indian populations).

Scott Freng is an Academic Professional Lecturer in the Department of Psychology at the University of Wyoming. His research examines the processes of implicit prejudice and stereotyping.

Helen Moore is Professor of Sociology and Women's Studies, and she is a Faculty Affiliate of Native American Studies at the University of Nebraska-Lincoln. Her research focuses on educational stratification, including race, class and gender issues as they link to economic structures. She currently is co-director of a National Institute of Mental Health Career Opportunities in Research grant for American Indian undergraduates.

\section{REFERENCES}

Abrahamson, Mark. 1983. Social Research Methods. Englewood Cliffs, NJ: Prentice Hall.

Adams, David Wallace. 1995. Education for Extinction: American Indians and the Boarding School Experience. Lawrence, KS: University Press of Kansas.

Aronson, Elliot. 2004. The Social Animal. 9th Edition. New York: Worth Publishing.

Banks, James and Cherrie A. Banks. 1996. Multicultural Education: Issues and Perspectives. 3rd ed. Boston, MA: Allyn and Bacon.

Becerra, Rosina M. and Ruth Zambrana. 1985. "Methodological Approaches to Research on Hispanics." Social Work Research and Abstracts 21:42-49.

Berry, John W. 1980. "Acculturation as Varieties of Adaptation." Pp. 9-25 in Acculturation: Theory, Models and Some New Findings, edited by Amado M. Padilla. Boulder, CO: Westview Press.

Blauner, Robert. 1972. Racial Oppression in America. New York: Harper and Row.

Bogdan, Robert C. and Sari K. Biklen. 1997. Qualitative Research for Education: An Introduction to Theory and Methods. 3rd ed. Boston, MA: Allyn and Bacon.

Cajete, Gregory. 1994. Look to the Mountain: An Ecology of lndigenous Education. Durango, CO: Kivaki Press.

Charleston, G. Mike. 1994. "Toward True Native Education: A Treaty of 1992." Journal of American Indian Education 33:10-56.

Chavez, Theresa and Matthew Pecos. 2000. "Santa Fe Indian School: Community Based Education Model." Paper presented at the annual conference of the National Association of Native American Studies, February, Houston, TX.

Child, Brenda J. 1998. Boarding School Seasons: American Indian Families 1900-1940. Lincoln, NE: University of Nebraska Press.

Coleman, Michael C. 1993. American Indian Children at School, 1850-1930. Jackson, MS: University Press of Mississippi.

Collins, Randall. 1971. "Functional and Conflict Theories of Educational Stratification." American Sociological Review 36:1002-1019.

Connors, Lori J. and Joyce L. Epstein. 1995. "Parent and School Partnerships". In Handbook of Parenting Applied and Practical Parenting, Vol. 4, edited by Marc H. Bornstein. Mahwah, NJ: Lawrence Erlbaum Associates.

Crawford, James. 1992. Hold Your Tongue. Reading, MA: Addison-Wesley Publishing Company.

Creswell, John W. 1998. Qualitative Inquiry and Research Design: Choosing among Five Traditions. Thousand Oaks, CA: Sage Publications.

Day, Priscilla, Elizabeth Blue, and Margaret Peake Raymond. 1998. "Conducting Research with an Urban American Indian Community: A Collaborative Approach." Journal of American Indian Education 37:2133.

DeJong, David. 1998. "Is Immersion the Key to Language Renewal?" Journal of American Indian Education 37:31-46.

1993. Promises of the Past: A History of Indian Education in the United States. Golden, CO: North American Press.

Deloria, Vine, Jr. 1982. "Education and Imperialism." Integrated Education 19:58-63.

Demmert, William G., Jr. 2001. Improving Academic Performance among Native American Students: A Review of the Research Literature. Charleston, WV: Clearinghouse on Rural Education and Small Schools: ERIC.

Deyhle, Donna. 1995. "Navajo Youth and Anglo Racism: Cultural Integrity and Resistance." Harvard Educational Review 65:403-444.

Deyhle, Donna and Frank Margonis. 1995. "Navajo Mothers and Daughters: Schools, Jobs, and the Family." Anthropology and Education Quarterly 26:135-167.

Deyhle, Donna and Karen Swisher. 1997. "Research in American Indian and Alaska Native Education: From Assimilation to Self-Determination." Review of Research in Education 22:113-194.

Dick, Galena Sells, Dan W.Estell, and Teresa L. McCarty. 1994. "Saad Naakih Bee'enootitji Na'alkaa: Restructuring the Teaching of Language and Literacy in a Navajo Community School." Journal of American Indian Education 33:31-46.

Dolce, Russell. 1985. "Attitude Toward and Manner of Dealing with Parents." Education 105:451-453. 
Epstein, Joyce L. 2001. School, Family and Community Partnerships: Preparing Educators and Improving Schools. Boulder, CO: Westview Press.

1995. "School/ Family/ Community Partnerships: Caring for the Children We Share." Phi Delta Kappan 76:701-712

1992. "School and Family Partnerships." In Encyclopedia of Educational Research, 6th Edition, Vol. 4, edited by Marvin C. Alkin. New York: Macmillan Publishing Company.

Evans, Ian M., Akiko Okifuji, and Alison D. Thomas. 1995. "Home-School Partnerships: Involving Families in the Educational Process." In Swing in School: Partnerships for Educational Change: Children, Youth and Change, edited by Ian M. Evans and Terry Cicchelli. Baltimore, MD: Paul H. Brookes Publishing Co.

Gettinger, Maribeth and Kristen Waters-Geutschow. 1998. "Parental Involvement in Schools: Parent and Teacher Perceptions of Roles, Efficacy, and Opportunities." Journal of Research and Development in Education 32:38-52.

Glaser, Barney and Anselm Strauss. 1967. Discovery of Grounded Theory: Strategies for Qualitative Research. Chicago, IL: Aldine Publishing Company.

Gollnick, Donna M. and Philip Chinn. 1998. Multicultural Education in a Pluralistic Society. 5th Edition. Upper Saddle River, NJ: Prentice Hall.

Griffith, James. 1996. "Relation of Parental Involvement, Empowerment, and School Traits to Student Academic Performance." Journal of Educational Research 90:33-41.

Kaufman, Phillip, Jin Y. Kwon, Steve Klein, and Christopher D. Chapman. 1999. "Dropout Rates in the United States: 1998." National Center for Education Statistics, U.S. Department of Education.

Ledlow, Susan. 1992. "Is Cultural Discontinuity an Adequate Explanation for Dropping Out?" Journal of American Indian Education 33:21-36.

Lightfoot, Sara Lawrence. 1981. "Toward Conflict Resolution: Relationships between Families and Schools." Theory into Practice 20:97-104.

Mehan, Hugh. 1992. "Understanding Inequality in Schools: The Contributions of Interpretive Studies." Sociology of Education 65:1-20.

Miller Cleary, Linda and Thomas Peacock. 1998. Collected Wisdom: American Indian Education. Boston, MA: Allyn and Bacon.

Nagel, Joane. 1996. American Indian Ethnic Renewal. New York: Oxford University Press.

Nichols, Claude Andrew. 1930. Moral Education among the Native American Indians. New York: Teacher's College, Columbia University.

No Child Left Behind. 2002. Washington, DC: U.S. Department of Education, Office of Elementary and Secondary Education.

Ogbu, John. 1995. "Cultural Problems in Minority Education: Their Interpretations and Consequences - Part One: Theoretical Background." The Urban Review 27:202-203.

Reyhner, Jon, 1992. “American Indians Out of School: A Review of School Based Causes and Solutions." Journal of American Indian Education 31:37-56.

Robinson-Zanartu, Carol and Juanita Majel-Dixon. 1996. "Parent Voices: American Indian Relationships with Schools." Journal of American Indian Education 36:33-54.

Rosenthal, Robert and Lenore Jacobson. 1966. "Teachers' Expectancies: Determinants of Pupils' IQ Gains." Psychological Reports 19:115-118.

Senese, Guy B. 1991. Self-Determination and the Social Education of Native Americans. New York: Praeger.

Shann, Mary H. 1998. "Professional Commitment and Satisfaction among Teachers in Urban Middle Schools." Journal of Educational Research 92:67-73.

Spring, Joel. 1997. Deculturalization and the Struggle for Equality. 2nd edition. New York: McGraw Hill.

Standing Bear, Luther. 1988. My Indian Boyhood. Lincoln, NE: University of Nebraska Press.

Steele, Claude M. 1997. "A Threat in the Air: How Stereotypes Shape Intellectual Identity and Performance." American Psychologist 52:613-629.

Steele, Claude M and Joshua Aronson. 1995. "Stereotype Threat and the Intellectual Test Performance of African Americans." Journal of Personality and Social Psychology 69:797-811.

Szasz, Margaret Connell. 1999. Education and the American Indian. Albuquerque, NM: University of New Mexico Press.

1988. Indian Education in the American Colonies, 1607-1783.

Albuquerque, NM: University of New Mexico Press.

Tempest, Phyllis. 1998. "Local Navajo Norms for the Wechsler Intelligence Scale for Children." Journal of American Indian Education 37:18-30.

Tierney, William. 1993. "The College Experience of Native Americans: A Critical Analysis." In Beyond Silenced Voices: Class, Race, and Gender in United States Schools, edited by Lois Weis and Michelle Fine. Albany, NY: State of New York Press.

Ward, Carol. 1995. “American Indian High School Completion in Rural Southeastern Montana." Rural Sociology 60:416-434.

Whitbeck, Les B., Dan R. Hoyt, Jerry D. Stubben, and Teresa LaFromboise. 2001. "Traditional Culture and Academic Success among American Indian Children in the Upper Midwest." Journal of American Indian Education 40:49-60. 